\title{
17 \\ DESTINY AND WORK ETHOS AS A DEGREE STRATEGY: Study in Vocational Community Katangka District Gowa
}

\author{
Mahmuddin \\ Fakultas Dakwah dan Komunikasi UIN Alauddin Makassar \\ mahmuddin.dakwah@uin-alauddin.ac.id
}

\begin{abstract}
Destiny and work ethic as a Da'wa strategy for the community in the Katangka Village, Gowa Regency. The problem is then broken down into several questions, namely: (1) What is the community's understanding of destiny in the Katangka Kelurahan, Gowa Regency? (2) Can the understanding of destiny encourage the work ethic of the community as a preaching strategy in the Katangka Kelurahan, Gowa Regency? This type of research is classified as qualitative with the research approach used is the sociological approach. The data source of this research is the community in Katangka Village, Gowa Regency. Data collection methods used were observation, interviews, questionnaires and documentation. Data processing and analysis techniques are carried out through three stages namely data reduction, data presentation and conclusion drawing. The results showed that people really believe in the destiny that was set by God from the beginning. The Katangka Kelurahan community understands it as a destiny of the provision of God that cannot be contested, there is also a destiny that requires an effort to change it and there is a destiny that can be known after that event occurs or known as destiny in human perspective. The community's view of destiny can encourage the community's work ethic as part of the Da'wa strategy it is said that destiny is a belief that comes from God and with that destiny the community is driven to seek that destiny by strengthening or doing hard work called the work ethic. Based on this research, the implications of the research are stated that the community should strengthen confidence in the provisions of God so that one continues to strive and work hard to achieve prosperity and meet their needs as part of the Da'wa strategy.
\end{abstract}

Keywords: Destiny, work ethic, da'wa strategy.

Abstrak: Takdir dan etos kerja sebagai strategi dakwah bagi masyarakat di Desa Katangka, Kabupaten Gowa. Masalahnya kemudian dipecah menjadi beberapa pertanyaan, yaitu: (1) Apa pemahaman masyarakat tentang nasib di Kelurahan Katangka, Kabupaten Gowa? (2) Dapatkah pemahaman tentang takdir mendorong etos kerja masyarakat sebagai strategi pengabaran di Kelurahan Katangka, Kabupaten Gowa? Jenis penelitian ini tergolong kualitatif dengan pendekatan penelitian yang digunakan adalah pendekatan sosiologis. Sumber data penelitian ini adalah masyarakat di Desa Katangka, Kabupaten Gowa. Metode pengumpulan data yang digunakan adalah observasi, wawancara, kuesioner dan dokumentasi. Teknik pengolahan dan analisis data dilakukan melalui tiga tahap yaitu reduksi data, penyajian data dan penarikan kesimpulan. Hasil penelitian menunjukkan bahwa orang benar-benar percaya pada takdir yang ditetapkan oleh Tuhan sejak awal. Masyarakat Kelurahan Katangka memahaminya sebagai takdir ketetapan Tuhan yang tidak bisa diganggu gugat, ada juga takdir yang membutuhkan upaya mengubahnya, dan ada takdir yang bisa diketahui setelah peristiwa itu terjadi atau dikenal dengan 
takdir manusia. perspektif. Pandangan masyarakat tentang takdir dapat mendorong etos kerja masyarakat sebagai bagian dari strategi dakwah dikatakan bahwa takdir adalah kepercayaan yang berasal dari Tuhan dan dengan takdir itu masyarakat didorong untuk mencari takdir itu dengan memperkuat atau melakukan kerja keras yang disebut etos kerja. Berdasarkan penelitian ini, implikasi dari penelitian ini menyatakan bahwa masyarakat harus memperkuat kepercayaan pada ketentuan Tuhan sehingga seseorang terus berusaha dan bekerja keras untuk mencapai kemakmuran dan memenuhi kebutuhan mereka sebagai bagian dari strategi dakwah.

Kata Kunci: Takdir, etos kerja, strategi dakwah.

\section{A. Introduction}

Poverty and ignorance are the most real enemies that Muslims must face today. How poverty and ignorance have made Muslims no longer a khairu ummah, but instead became su'ul ummah. One reason is because Muslims have low employment ethics, even though Islam is a religion that upholds the values of goodness for humans. ${ }^{387}$

From the facts stated above, namely the negative influence and positive influence of people's understanding of destiny and its influence on work performance and the aspects behind it can be traced through this research. With the information obtained through research, it is possible for various ideas of participation to neutralize the negative symptoms of religious understanding in developing societies, especially the understanding of destiny.

Religion in one aspect is the belief in God (God and so on), with the teachings of worship and obligations associated with that belief (Islam, Christianity, Hinduism, and Buddhism). ${ }^{388}$ One aspect of belief in God is belief in the existence of destiny determined by God.

From this view, the approach used is a sociological and multi-disciplinary approach, so that this study will reveal various problems from several approaches that are adapted to the object of this study. Besides that, a rationalistic approach is used. While the phenomenological approach means that this research has flexibility in such a way as to look at the problems that are the focus of its attention so that the truth of scientific information obtained is as much as possible in accordance with the natural realities of the field.

He purposes of this research is to reveal the influence of religious teachings in encouraging community work motivation as part of the da'wa strategy for their survival in the future and to find out people's understanding of destiny, its relationship with improving work ethic.

The public's view of destiny, they are not uniform, there is a view that destiny has a positive dimension, namely the existence of trust in destiny, it can provide enthusiasm for life and work enthusiasm in seeking prosperity and happiness in life in the world, because they assume that no one knows in a way must be about his destiny. On the other hand, there are those who think that destiny has been determined by God, therefore, he is pessimistic and all activities are left to God. They assumed that if God predestined me something good, then surely, I would be a good person, humans are not free to determine themselves, what humans do is essentially God's doing.

Kartini Kartono views work as a basic activity and is an essential part of human life, work gives status and binds someone to other individuals and society. ${ }^{389}$

Based on the description above, this research has an orientation to explore the community's view of destiny and its relation to an increase in work ethic, with the main issues raised as follows: how is the community's understanding of destiny and whether the

387 Mia Fitriah Elkarimah, Etos Kerja Islami Dalam Mewujudkan Kesejahteraan Sosial, An-Nuha, Vol. 3, No. 1, Juli 2016.

388 Penyusun Kamus Pusat Pembinaan dan Pengembangan Bahasa, Kamus Besar Bahasa Indonesia, (Cet. III; Jakarta: Balai Pustaka, 1990), h. 9.

${ }^{389}$ Kartini Kartono, Psikologi Sosial Untuk Manajemen Perusahaan dan Industyri, (Jakarta: PT. Raja Grafindo Persada, 1994), h. 145-146. 
understanding of destiny can encourage the community work ethic as a preaching strategy in the Kelurahan Katangka Gowa Regency?

\section{B. Literature Review}

\section{Problems of Fate}

Qadar or destiny is to regulate everything in an orderly manner and determine the limits of the end. Then the meaning of the words of all things according to the qadha of Allah and His qadar is that everything is realized according to the decree of God and the orderly principle according to what God knows will. Qodho 'meaning is something that God has set for His creatures, whether in the form of creation, negation, or change in something. While the meaning of qodar is something that has been determined by God since the time of azali. Thus, there is first qodar then followed by qodho '.390

Talking about destiny means going to discuss something that is very complicated and requires coherent analysis, so that you can truly differentiate from one another. The complexity is often found incomplete explanations and tends to confront a similar problem, even often found in the argument of the Koran and Hadith which explains that all the events in this world have been recorded in Lauh Mahfudz. ${ }^{391}$

Another view reveals that the problem of destiny can be easily understood when viewed from the perspective of God's perspective, the perspective of angels and the perspective of humans. 1) Destiny in the perspective of God who mubram without exception, everything has been known and predetermined and reality (qadar) in time. This side is not possible to change at all because there is a change at this level is the same as the things that are not known to God. 2) Destiny in the Angel's perspective. Angels have a variety of tasks, according to the will of God who created them. In the perspective of this angel, the destiny of every human being recorded in the Lawh Mahfudz some are already mubram (patents cannot change) and some are still mu'allaq (conditional). Likewise, guidance, disease, age or whatever happens to the Fulan. ${ }^{392} 3$ ) Fate in a human perspective. Angels see the destiny of mubram and mu'allaq, humans can only fully know the mu'allaq side only when the time has not arrived

Imam Ibn Hajar explained that in fact what Allah had known was completely unchanging and changing. What can change and change is the actions of someone who appears to humans and who appears to the guardian angels (Hafadhah) and who are assigned to interact with humans (al-Muwakkilin). So, in this case the determination and elimination of destiny occurs, such as about increasing age or decreasing. As for in Allah's knowledge, there is no abolition or determination. ${ }^{393}$ "It is further said that Imam Ibn Hajar al-Asqalani explained that" The abolition and determination of destiny is in the perspective of what angels know and what is recorded in the Lawh Mahfudz (Ummul Kitab). As for in Allah's knowledge, there is no abolition at all. This knowledge of God is called destiny mubram, and the knowledge of angels is called destiny mu'allaq. "394

Humans can only know of the fate of Mubram who befalls them only when something has happened. For example, things related to his birth, things that have been or have not been achieved at his present age and everything that has happened in the past and cannot be changed.

390 Syaikh Muhammad bin Sholih al 'Utsaimin; Syarh al 'Aqidah al Wasithiyah, Dalam kitab Syarh al 'Aqidah al Washitiyah. Kumpulan Ulama. Penerbit Daarul Ibnul Jauzi; t. th.), h. 551.

391 Abdul Wahab Ahmad, Wakil Katib PCNU Jember dan Peneliti di Aswaja Center Jember. http://www.nu.or.id/post/read/ 96195/mengurai-takdir-dari-tiga-perspektif-allah-malaikat-danmanusia (26-1-2019).

392 Abdul Wahab Ahmad, Wakil Katib PCNU Jember dan Peneliti di Aswaja Center Jember. http://www.nu.or.id/post/read/ 96195/mengurai-takdir-dari-tiga-perspektif-allah-malaikat-danmanusia (26-1-2019).

393 Ibnu Hajar al-Asqalani, Fath al-Bâri, (juz X, t.th.) h. 488.

394 Ibnu Hajar al-Asqalani, Fath al-Bâri, (juz X, t.th.) h. 416. 
Humans can know the age of a person who has mubramed only when that person has positively died. 395

Human actions since the beginning have been determined by God. Actions do not arise from one's own free power and strength. Man's actions that are manifested in the form of work are no different from puppets that do not move and later move when the mastermind moves them. The consequence is the emergence of community understanding that work creativity is determined by God, even it is said that human activity is God's activity.

Some people have the wrong assumption in understanding destiny. They only surrender to destiny without making any effort at all. Really, this is a real mistake. ${ }^{396}$

\section{Work Ethic Problems}

The words of work ethic are often heard in the midst of the general public, especially among bureaucrats or a government or private organization. Work ethic is the work spirit that characterizes and believes a person or a group.

Work Ethics Simply put, ethos can be defined as the basic character of a society. Embodiment of ethos can be seen from the structure and social norms of society. As the basic character of society, ethos becomes the foundation of one's own behavior and the surrounding environment, which radiates in people's lives. ${ }^{397}$

The work ethic as a positive value system really supports the task implementation effort. The main principle in the work ethic is at least 2 things: work is worship and rank and position is trustful.

Another view put forward by Imam S Hidayat about the ethics of the Islamic profession, there are some things that are proper and inappropriate for every Muslim in developing his profession, especially in business and in everything that can be analogous to business, he divides into 10 ethics namely: seeking fortune, hard work, sincere, honest, cooperation, balance, looking forward, prohibiting begging, prohibiting monopoly, and prioritizing quality / neatness. ${ }^{398}$

The Muslim work ethic is defined as a personality attitude that gives birth to a very deep conviction that work is not only to glorify himself, reveal his humanity, but also as a manifestation of pious deeds. ${ }^{399}$

Someone who works is based on the nature of being a human being and based on the principle of unity of faith in Allah, then he has shown as a Muslim with dignity. If someone is reluctant to exploit his potential to work in accordance with his nature, then he is among those who oppose his nature and even reduce his degree as a human being.

According to Tri Setyo there are four parameters that are usually used to see a person or group has a work ethic or not. First, how does one view work. The second parameter is the presence or absence of enthusiasm for doing work, enthusiasm for working or completing work. The third parameter, there are efforts to perfect work to be more productive. As for the fourth parameter, there is pride in being able to do the work that is his duty. 400

\footnotetext{
395 Abdul Wahab Ahmad, Wakil Katib PCNU Jember dan Peneliti di Aswaja Center Jember. http://www.nu.or.id/post/read/ 96195/mengurai-takdir-dari-tiga-perspektif-allah-malaikat-danmanusia (26-1-2019).

${ }^{396}$ Syaikh Sholih Al Fauzan, Al Irsyaad ilaa Shahiihil I'tiqad, (Cet. I: t.tp. Maktabah Salsabiil, 2006), h. 245246.

397 Clifford Geertz, Tafsir Kebudayaan, (Yogyakarta: Kanisius Press, 2016), h. 127.

398 Imam S Hidayat, Etos Kerja Sesuai Dengan Etika Profesi Islam, Mimbar, Volume XXII No. 1 Januari Maret 2006: 130-142.

399 Zainal Abidin, Pengertian Dan Maksud Etos Kerja Islam (Muslim). http://ikumpul.blogspot.com/2013/05/pengertian-maksud-etos-kerja-islam-muslim.html (26-1-2019). 400 Tri Setyo, Etos Kerja Tinggi Cermin Kepribadian Muslim Unggul, Wahana Akademi, Volume 3 Nomor 2, Oktober 2016, h. 140.
} 
According to Nurcholish Madjid, the work ethic in Islam can be understood as a Muslim's belief that the work done is related to his life purpose. 401 Work ethic emanates from the system of faith, the system of faith is synonymous with the attitude of life. It is a source of motivation and a source of value for the formation of an Islamic work ethic. ${ }^{402}$

Based on the above view, it needs to be seen from the foundation of the Koran which is found in the QS. At-Taubah: 105. as-Shabuni clarify the verse by saying that the verse is in the form of amar (command). Work! Work on it! Work as much as you can! Indeed, of all types of activities, there is nothing hidden from Him. And surely Allah, His apostles and believers will see and judge the results of your performance. ${ }^{403}$

\section{Problems of Da'wa Strategy}

Strategy is the art and science of planning and directing military operations on a large scale. ${ }^{404}$ Strategy is a means of achieving long-term goals. Strategy is a potential action that requires satisfaction at the top level of management and enormous company resources. The strategy influences the long-term sustainability of a company, usually at least five years, thus the strategy is oriented towards the future. 405 Strategy is a broad overall priority or direction taken by the organization. Strategies are choices about how best to achieve the organization's mission. 406

While David ${ }^{407}$ stated that Strategy Management is "Strategic management can be defined as the art and science of formulating, implementing, and evaluating cross-function decisions that enable an organization to achieve its objectives.

Da'wa strategy is a combination of Da'wa planning and management to achieve a goal. In achieving these objectives, the da'wa strategy must be able to demonstrate how operational techniques must be carried out, in the sense that the approach can differ at any time depending on the situation and conditions. 408

Anwar Arifin (as quoted by Mahmuddin) states that the definition of 'strategy as the right collaboration of all elements of da'wa starting from the preacher or preacher as well as their organization or institution, messages, methods and media in appropriate with the audience condition and situation. . $^{409}$

The same was stated by Moh. Ali Aziz stated that who defines da'wa strategy as a plan with a series of activities designed to achieve the objectives of certain da'wa. In order to achieve these objectives, several things need to be put into attention such as: (1) strategy or plan forda'wa, which requires methods and utilization of various resources; and (2) how the strategies are prepared to achieve certain goals. 410

401 Nurcholish Majid, Islam Agama Kemanusiaan, (Jakarta: Paramadina, 2005. 2005), h. 216.

402 Rahmawati Caco, Etos Kerja (Sorotan Pemikiran Islam), dalam Farabi Jurnal Pemikiran Konstruktif Bidang Filsafat dan Dakwah, (terbitan Fakultas Ushuluddin dan Dakwah IAIN Sultan Anai Gorontalo, Vol. 3, No. 2, 2006, h. 68-69).

403 Ash-Shabuni, Shafwatut Tafasir, Juz I, Beirut: Darul Fikr, tth.). h. 561.

404 Suyadi Prawirosentono, Dewi Primasari, Manajemen Stratejik dan Pengambilan Keputusan Korporasi (Stragec Management \& Corporate Decision Making), (Cet. II; Jakarta: Bumi Aksara, 2016), h. 3.

405 Fred R. David, Strategic Management (Consep and Cases), Thirteenth Edition (Francis Marion University, Florence, South Carolina. h. 3.

406 Qudrat Nugraha, Manajemen Stratsgis (Modul), h. 1.2.

${ }^{407}$ Rahayu Puji Suci, Esensi Manajemen Strategi (Zifatama, Taman Sidoarjo, 2015), h. 3

408 Mahmuddin, Strategi Dakwah Terhadap Masyarakat Agraris, Jurnal DakwahTabligh, Edisi XXVII; Vol. 14 No. 1 Juni 2013: 101-113.

${ }^{409}$ Mahmuddin, Asyraf Hj.Ab Rahman, Andi Haris, Andi Tenri Citra Haris and Hadriaty, Da'wah Strategy In Strengthening The Community's Economy in Bira Village Bulukumba Regency, Indonesia. http://www.iaeme.com/IJCIET/index.asp, h. 116-122.

410 Mahmuddin, Asyraf Hj.Ab Rahman, Andi Haris, Andi Tenri Citra Haris and Hadriaty, Da'wah Strategy In Strengthening The Community's Economy in Bira Village Bulukumba Regency, Indonesia. http://www.iaeme.com/IICIET/index.asp, h. 116-122. 
According to Daud Ismail According to Sayyid Qutb, Muslims' responsibility in upholding their religious duties including calling people to the right path (da'wa) are much related to their duty and responsibility as Allah's vicegerent (caliph) on this earth. This will include showing good examples in conduct and more importantly their religious commitment to other fellow men.411

Thus it can be seen that the da'wa strategy intended in this study is the da'wa effort in neutralizing the community's views with regard to understanding of destiny and work ethic.

\section{Methodology}

This research was conducted in Katangka Village, Somba Opu District, Gowa Regency, South Sulawesi Province. This research uses a sociological approach and a communication approach. The data source is primary data and secondary data by collecting all information obtained from religious leaders, community leaders, individuals or community groups. That information is the basis for analyzing research objects that are related to destiny and work ethic. In accordance with the type, characteristics, and sources, the data collection in all study activities was carried out several interview techniques, questionnaires, observations and documentation. The tools used in this study are all the facilities needed in this study. The means can be in the form of stationery, sound suppression devices, communication equipment, vehicles and all its traps, shooting tools and everything related to this research. The analysis technique uses a qualitative approach with the aim of gaining depth and integrity of information regarding destiny and work ethic in the community of Kelangkaana Katangka, Gowa Regency. Strategic analysis starts from data and leads to general conclusions. After some data is collected, then it is processed and clarified the validity of the data, then it is reexamined that there may be data errors, so that is when testing the validity of the data obtained is used.

\section{Results and Discussion}

Community Understanding Katangka Gowa Regency About Destiny.

\section{Community belief in the existence of destiny}

The Katangka Kelurahan community believes in the existence of destiny as God's provision for everything that has to do with human life. This was revealed when filling out a questionnaire related to questions about people's views related to the destiny and provision of God in this life. The questionnaire shows that there are 92 people (100\%) who agree or believe that there is a destiny determined by Allah.

Suwandi (60 years) stated that the rules that run in this world are regulated based on the destiny that was established by God from the beginning. ${ }^{412} \mathrm{~A}$. Marsuki (50 years) argues that destiny is a decree of God that has been established by God and is God's prerogative to determine it. ${ }^{413}$ Harianto (55 years) stated that destiny is like water flowing from upstream to downstream and looking for a low place in accordance with the path established by God, nothing happens in this world except for the decree of Allah Almighty. ${ }^{414}$

\section{Community beliefs about the fate of mubram.}

Mubram's destiny or destiny are already patents and cannot be changed in any way. For example, destined to be born from which parent, date of birth. The Katangka Village community believes that the fate of the Mubram is a predetermined destiny and is a destined patent and cannot be changed and has never even been exchanged with others, because it is impossible for a

${ }^{411}$ Mahmuddin, Asyraf Hj.Ab Rahman, Andi Haris, Andi Tenri Citra Haris and Hadriaty, Da'wah Strategy In Strengthening The Community's Economy in Bira Village Bulukumba Regency, Indonesia. http://www.iaeme.com/IJCIET/index.asp, h. 116-122.

412 Suwandi (60 tahun), Masyarakat, Wawancara, di Katangka, 15 April 2019.

413 A. Marsuki (50 tahun), Tokoh Agama, Wawancara, di Katangka, 30 April 2019.

${ }^{414}$ Harianto (55 tahun), Tokoh Masyarakat, Wawancara, di Katangka, 21 Mei 2019. 
person born from a poor family to be said to have been mistakenly born who should have been born from a family rich.

Takbir Zamzam (57 years) states that the destiny of mubram is a destiny that is not possible to change and may not even be replaced by other people, because it is already God's determination as God's prerogative. ${ }^{415} \mathrm{Abd}$. Rauf (65 years) states that such a destiny has become the sole authority and right of God, this human being only lives his destiny and resigns to his provisions. ${ }^{416}$

\section{Community trust in your destiny mu'allaq.}

Fate mu'allaq or believe that Allah will change one's destiny according to his efforts and hard work, while those who claim not to believe that Allah will change one's destiny according to the workload of 14 people $(15 \%)$.

Ahmad Fauzi (60 years old) states that God will change someone's fate if someone works and is diligent in his work. ${ }^{417}$ While Burhanuddin (50 years old) argues that the destiny of mu'allaq is that humans live their destiny while trying to change their destiny with effort and hard work. 418 There is Andi Marsuki (49 years) mentioned that destiny is basically determined by God before birth, but there is a destiny that can change with prayer and hard work, this destiny of mu'allaq is a destiny that can change with hard work. ${ }^{419}$

\section{The public's view of destiny in God's perspective.}

Destiny in the perspective of God who mubram without exception, everything has been known and predetermined and reality (qadar) in time. From this side there will be no change from that destiny. Destiny in God's perspective is absolute, this is proven that those who agree and strongly agree with fate in God's perspective reach 90 people or $98 \%$, while those who express doubt reach $2 \%$ or 2 respondents, whereas those who disagree and strongly disagree agree to reach $0 \%$, it means that respondents believe that God's destiny is absolute.

Suwandi (60 years) revealed that destiny according to God's perspective is a destiny that cannot be negotiable for its determination, because it has been determined by Allah, the almighty over everything, and no power for humans to reject it. ${ }^{420}$ Ahmad Fauzi (60 years) considers that the destiny in God's perspective is a destiny that has been determined by God from the beginning and cannot change and will not even move on to others. ${ }^{421}$

\section{The public's view of destiny in the perspective of angels.}

Destiny in the angelic perspective shows that those who agree and strongly agree reach 87 people or $95 \%$, while those who are hesitant reach 3 people or $3 \%$ and those who say disagree reach 2 people or $2 \%$, while those who strongly disagree reach 0 people or $0 \%$. So, it can be understood that the respondent views that fate in the perspective of angels is a patent that cannot be contested anymore or whether it still depends on some of the conditions chosen by Fulan.

Harianto (55 years) states that if someone works hard according to the rules, then it is likely to get a lot of luck and that is the fate that he receives, but if someone chooses to be lazy, then their destiny is poor, because they are not trying to find a reski has been prepared by God. 422 Alimuddin (61) said that reski must be sought and the path of destiny is by trying, destiny has been prepared, but there needs to be a path to the achievement of destiny. ${ }^{423}$ Therefore, to achieve

415 Takbir Zamzam (57 Tahun), Tokoh Agama, Wawancara, di Katangka, 25 April 2019.

${ }^{416}$ Abd. Rauf (66 Tahun). Tokoh Masyarakat, Wawancara, di Katangka, 15 Juni 2019.

${ }^{417}$ Ahmad Fauzi (60 tahun), Tokoh Agama, Wawancara, di Katangka, 14 Juli 2019.

${ }^{418}$ Burhanuddin (45 tahun), Pegawai Negeri Sipil, Wawancara, di Katangka, 14 April 2019.

${ }^{419}$ A. Marsuki (50 tahun), Tokoh Agama, Wawancara, di Katangka, 30 April 2019.

${ }^{420}$ Suwandi (60 tahun), Masyarakat, Wawancara, di Katangka, 15 April 2019.

${ }^{421}$ Ahmad Fauzi (60 tahun), Tokoh Agama, Wawancara, di Katangka, 14 Juli 2019.

${ }^{422}$ Harianto (55 tahun), Tokoh Masyarakat, Wawancara, di Katangka, 21 Mei 2019.

${ }^{423}$ Alimuddin (60 tahun), Kepala Lingkungan Lakiyung, Wawancara, di Lakiyung, Katangka, 17 April 2019. 
a predetermined destiny must be endeavored and lived according to the provisions and provisions of God.

Thus, it can be understood that destiny from the perspective of angels is predestined from the start, but it requires effort and hard work to achieve that destiny.

\section{The public's view of destiny in a human perspective.}

As for the knowledge of Allah, there is no abolition or determination. Destiny in human perspective as many as 80 people (87\%), while those who are hesitant to reach 4 people $(4 \%)$, who stated disagree as many as 6 souls (7\%), while those who strongly disagree reached 2 souls $(2 \%)$, so that those who disagree and disagree reach 8 people or $9 \%$.

Observing the results of the questionnaire above shows that the views of the community are not uniform in response to destiny in a human perspective, because there are still $13 \%$ who are hesitant and disagreeable and strongly disagree with regard to the destiny.

\section{Destiny Can Encourage Work Ethics as a Da'wa Strategy in the Katangka Community of Gowa Regency}

Paying attention to the views of the people of Katangka Village, Somba Opu Subdistrict, Gowa Regency, South Sulawesi, about destiny, which generally believes that destiny is determined by Allah. Therefore, in this description the researchers see the relationship between destiny with work ethic as a propaganda strategy can encourage or be a trigger in working so that life can improve from before. To find out this understanding, the researcher elaborates on that understanding one by one.

\section{Community understanding of destiny according to God's command can encourage the work ethic of society.}

Destiny determined by God can encourage the work ethic of the community, while those who express doubt reach 13 people (14\%) and those who disagree and strongly disagree reach 6 people (6\%). Thus, it can be seen that in general the Katangka Kelurahan community is of the view that with the predetermined destiny of God it can encourage the work ethic of the community. This is part of the da'wa strategy.

a. Marsuki (50 years) argues that the destiny that has been set by God is a stepping stone or a determination that needs to get effort and work to achieve it, that destiny will not come alone without any effort to achieve it. 424

Rahmariati (22 years) states that the destiny that has been determined by God only lives it and seeks and tries to achieve it, because destiny will not be achieved if it is not attempted. ${ }^{425}$ Nurafia Afiifah el-Mahirah (23 years) states that destiny is the decree of God, humans cannot walk outside the destiny set by God. 426

The application of destiny and work ethic in a business, is one of the da'wa strategies in achieving the objectives of da'wa, because society is an object of da'wa that needs to be entered through various perspectives, including at the door of destiny and work ethos.

\section{Community understanding of destiny according to Persi Angels can encourage the community work ethic}

Destiny is related to the understanding which states that if the Fulan works hard, then his destiny is rich while if he chooses to be lazy then his destiny becomes a poor person, including regarding guidance, illness, age or whatever happens to the Fulan all including destiny according to the Persian Angel.

\footnotetext{
${ }^{424}$ A. Marsuki (50 tahun), Tokoh Agama, Wawancara, di Katangka, 30 April 2019.

425 Rahmariati (22 tahun), Mahasiswa, Wawancara, di Katangka, 27 April 2019.

426 Nurafia Afiifah el-Mahirah (23 tahun), Mahasiswa, Wawancara, 18 Mei 2019.
} 
Takbir Zamzam (57 years) that if someone has been destined to become rich but not followed by effort, then he cannot reach that destiny, because that destiny can be achieved if there is effort and hard work. ${ }^{427}$ Abd. Rauf (65 years) argues that destiny is like a deposit that Allah keeps in a hidden place, later humans will search for these deposits with diligent effort. ${ }^{428}$ Ahmad Syuaib (60 years) stated that destiny is a decree of God that is a secret for him (human), to get it requires effort and hard work. ${ }^{429}$

Considering the above discussion, it can be understood that destiny according to Angel's perception can encourage someone to always work to achieve that destiny, because that destiny must have an effort to achieve it. This view indicates the existence of da'wa efforts in applying it through various perspectives, so that the public understands religious issues comprehensively. That is why the da'wa strategy needs to be packaged in various doors and moments in applying it.

\section{Community's understanding of destiny according to human persi can encourage the community work ethic.}

Humans can only know of the fate of Mubram who befalls them only when something has happened. Understanding such a destiny, by the community of Katangka there was a difference of opinion, the Destiny can encourage the work ethic of the community, while those who expressed doubt reached 13 people (14\%) and those who said they did not agree and strongly disagreed reached 3 people (3\%). Thus, it can be seen that around $83 \%$ who stated that destiny with human persi can be used as a driver of the community work ethic

Hj. Hatijah (65 years) argues that humans are only able to know the destiny according to the human persi after the event occurs, but often found the existence of symptoms to the path of destiny, meaning that one can predict destiny before the occurrence of destiny and God's provisions. ${ }^{430}$ Burhanuddin ( 45 years) mentioned that the ability of humans to know the destiny according to the human persi is very limited and even can hardly predict it, humans can only know after the event. 431

Thus, it can be understood that humans are very limited in knowing their destiny before it is reached, so humans need to work hard to achieve their hopes until their death. The da'wa efforts become part of the da'wa strategy that needs to be developed and continuously implemented to enter all aspects of the life of the ummah, so that the ummah can be enlightened and be able to fully understand religion.

\section{Community understanding that by working hard can change one's destiny.}

Working hard can achieve maximum results, so too in Islam it is emphasized the need for hard work to achieve a decent life, with hard work can change one's destiny, while those who express doubt reach 6 souls (7\%), and those who declare no agree and strongly disagree reach 6 souls $(6 \%)$. Thus, it can be seen that there are $87 \%$ who understand that by working hard can change one's destiny.

Takbir Zamzam (57 years old) stated that one must not stand idly by waiting for destiny, but one should work hard if he wants to change his destiny for the better. ${ }^{432}$ Alimuddin (60 years) said that destiny and hard work are like two sides of a coin that cannot be separated, because if someone works hard, then there will be awaited outcome while changing one's destiny. 433

\footnotetext{
427 Takbir Zamzam (57 Tahun), Tokoh Agama, Wawancara, di Katangka, 25 April 2019.

428 Abd. Rauf (66 Tahun). Tokoh Masyarakat, Wawancara, di Katangka, 15 Juni 2019.

${ }^{429}$ Ahmad Syuaib (60 tahun), Masyarakat, Wawancara, di Katangka, 12 April 2019.

${ }^{430} \mathrm{Hj}$. Hatijah (65 tahun), Ketua Majelis Taklim Al-Ikhlas, Wawancara, di Katangka, 17 April 2019.

${ }^{431}$ Burhanuddin (45 tahun), Pegawai Negeri Sipil, Wawancara, di Katangka, 14 April 2019.

432 Takbir Zamzam (57 Tahun), Tokoh Agama, Wawancara, di Katangka, 25 April 2019.

433 Alimuddin (60 tahun), Kepala Lingkungan Lakiyung, Wawancara, di Lakiyung, Katangka, 17 April 2019.
} 
From this description it can be understood that if someone works hard, then his destiny will be in accordance with his efforts. With this understanding, the people in Katangka Village can be enlightened and understand themselves as people who need to understand their religion perfectly. This is what is called the Da'wa strategy, although it does not need to be clarified that it is part of the Da'wa strategy, but the practice and its implementation are Da'wa strategies.

\section{Community's understanding/agreement on destiny that reski, age and soul mate are predetermined destinies of God that cannot change.}

This provision is a predetermined provision of God. Reski, age and soul mate could not be changed and exchanged, while those who expressed doubt reached 4 people $(4.3 \%)$ and those who said they did not agree and strongly disagreed reached 4 people (4.3\%). Thus, it can be seen that the public's view that destiny, age, soul mate and reski cannot be changed and exchanged.

Suwandi (60 years old) states that soul mate, reski and age will never decrease and increase, it is in accordance with the provisions of Allah. ${ }^{434} \mathrm{Abd}$. Rauf (66 years) states that if someone dies by committing suicide, then even that is included in the destiny set by God, his death is by Allah's provisions not because of drinking poison and the like. 435

The reaction from that view becomes a stepping stone in entering people's thoughts on the importance of the da'wa strategy in providing understanding to the community, so that the community can be more confident that the achievement of such understanding can be achieved due to the da'wa strategy applied by the preacher long before this research was conducted.

\section{Community understanding that reski can change depends on the conditions and hard work done.}

Reski destiny can change with conditions and hard work, reski destiny can change depending on the conditions and hard work done by someone, while those who expressed doubt reached 5 lives (5.4\%), and those who stated disagree and strongly disagree reached 5 people (5.4\%). Thus, it can be understood that there are $89.2 \%$ who think that the fate of Reski can change with hard work.

In contrast to the initial statement that Reski cannot change, it can be understood that change requires effort and prayer, because hard work and prayer can change one's destiny.

Takbir Zamzam (57 years) states that the unchangeable reaction is a fateful fate that is not followed by effort and hard work, he mentioned that God will not change the fate of a people, except the people themselves who change it. So, that reski can change according to his efforts, of course destiny will be changed with destiny as well.436

Thus, the application of the da'wa strategy contained in providing understanding to the community related to destiny and work ethic is a da'wa effort in achieving the target of understanding to the community.

\section{E. Conclusion}

The results showed that people really believe in the destiny that was set by God from the beginning. The destiny is divided into three namely destiny according to God's perspective, destiny according to the perspective of angels and destiny in human perspective. The Katangka Kelurahan community understands it as a destiny of the provision of God that cannot be contested, there is also a destiny that requires an effort to change it and there is a destiny that can be known after that event occurs or known as destiny in human perspective. The community's view of destiny can encourage the community's work ethic as part of the da'wa strategy it is said that destiny is a belief that comes from God and with that destiny the community is driven to seek that destiny by strengthening or doing hard work called the work ethic.

\footnotetext{
434 Suwandi (60 tahun), Masyarakat, Wawancara, di Katangka, 15 April 2019.

435 Abd. Rauf (66 Tahun). Tokoh Masyarakat, Wawancara, di Katangka, 15 Juni 2019.

436 Takbir Zamzam (57 Tahun), Tokoh Agama, Wawancara, di Katangka, 25 April 2019.
} 


\section{References}

Al Qur'an al-Karim

Abidin, Zainal. Pengertian Dan Maksud Etos Kerja Islam (Muslim). http://ikumpul.blogspot.com/2013/05/pengertian-maksud-etos-kerja-islam-muslim.html (26-1-2019).

Ahmad, Abdul Wahab. Wakil Katib PCNU Jember dan Peneliti di Aswaja Center Jember. http://www.nu.or.id/post/read/ 96195/mengurai-takdir-dari-tiga-perspektif-allahmalaikat-dan-manusia (26-1-2019).

al 'Utsaimin, Syaikh Muhammad bin Sholih. Syarh al 'Aqidah al Wasithiyah, Dalam kitab Syarh al 'Aqidah al Washitiyah. Kumpulan Ulama. Penerbit Daarul Ibnul Jauzi; t. th.

Al Fauzan, Syaikh Sholih. Al Irsyaad ilaa Shahiihil I'tiqad, Cet. I: t.tp. Maktabah Salsabiil, 2006.

al-Asqalani, Ibnu Hajar. Fath al-Bâri, (juz X, t.th.)

Ash-Shabuni. Shafwatut Tafasir, Juz I, Beirut: Darul Fikr, tth.

Caco, Rahmawati. Etos Kerja (Sorotan Pemikiran Islam), dalam Farabi Jurnal Pemikiran Konstruktif Bidang Filsafat dan Dakwah, terbitan Fakultas Ushuluddin dan Dakwah IAIN Sultan Anai Gorontalo, Vol. 3, No. 2, 2006, h. 68-69.

David, Fred R. Strategic Management (Consep and Cases), Thirteenth Edition (Francis Marion University, Florence, South Carolina.

Elkarimah, Mia Fitriah. Etos Kerja Islami Dalam Mewujudkan Kesejahteraan Sosial, An-Nuha, Vol. 3, No. 1, Juli 2016.

Geertz, Clifford. Tafsir Kebudayaan, Yogyakarta: Kanisius Press, 2016).

Hakami, Syaihk Hafidz bin Ahmad. Ma'aarijul Qobuul, Cet. I; Darul Kutub 'Ilmiyah, 1424 $\mathrm{H} / 2004$.

Hidayat, Imam S. Etos Kerja Sesuai Dengan Etika Profesi Islam, Mimbar, Volume XXII No. 1 Januari - Maret 2006: 130-142.

Kartono, Kartini. Psikologi Sosial Untuk Manajemen Perusahaan dan Industyri, (Jakarta: PT. Raja Grafindo Persada, 1994.

Mahmuddin, Asyraf Hj. Ab Rahman, Andi Haris, Andi Tenri Citra Haris and Hadriaty, Da'wa Strategy In Strengthening The Community's Economy in Bira Village Bulukumba Regency, Indonesia. http://www.iaeme.com/IJCIET/index.asp, h. 116-122.

Mahmuddin, Strategi Dakwah Terhadap Masyarakat Agraris, Jurnal DakwahTabligh, Edisi XXVII; Vol. 14 No. 1 Juni 2013: 101-113.

Majid, Nurcholish. Islam Agama Kemanusiaan, Jakarta: Paramadina, 2005. 2005.

Nugraha, Qudrat. Manajemen Stratsgis (Modul)

Penyusun Kamus Pusat Pembinaan dan Pengembangan Bahasa, Kamus Besar Bahasa Indonesia, Cet. III; Jakarta: Balai Pustaka, 1990.

Prawirosentono, Suyadi. Dewi Primasari, Manajemen Stratejik dan Pengambilan Keputusan Korporasi (Stragec Management \& Corporate Decision Making), Cet. II; Jakarta: Bumi Aksara, 2016. 
Setyo, Tri. Etos Kerja Tinggi Cermin Kepribadian Muslim Unggul, Wahana Akademi, Volume 3 Nomor 2, Oktober 2016.

Suci, Rahayu Puji. Esensi Manajemen Strategi, Zifatama, Taman Sidoarjo, 2015. 